\title{
História, tempo presente e testemunho: ainda em torno dos limites da representação
}

\author{
Alexandre de Sá Avelar \\ Universidade Federal de Uberlândia
}

Há dois anos, durante os primeiros dias que sucederam ao nosso retorno, estávamos todos, eu creio, tomados por um delírio. Nós queríamos falar, finalmente ser ouvidos. Diziam-nos que nossa aparência fisica era suficientemente eloquente por ela mesma. Mas nós justamente voltávamos, nós trazíamos conosco nossa memória, nossa experiência totalmente viva e nós sentíamos um desejo frenético de a contar tal qual. E desde os primeiros dias, no entanto, parecia-nos impossível preencher a distância que nós descobrimos entre a linguagem de que dispúnhamos e essa experiência que, em sua maior parte, nos ocupávamos ainda em perceber nos nossos corpos. (...) Essa desproporção entre a experiência que nós havíamos vivido e a narração que era possível fazer dela não fez mais do que se confirmar em seguida. Nós nos defrontávamos, portanto, com uma dessas realidades que nos levam a dizer que elas ultrapassam a imaginação. Ficou claro então que seria apenas por meio da escolha, ou seja, ainda pela imaginação, que nós poderíamos tentar dizer algo delas. ${ }^{1}$

Uma das marcas da atual paisagem historiográfica, situada por 'retornos' e ampliações de objetos, métodos e teorias, é, sem dúvida, o crescente interesse por temas do presente. Essa imersão em problemáticas mais contemporâneas tem recebido distintas denominações: presentismo, história imediata, história do tempo presente, entre outras com menor fortuna crítica. O estudo de fenômenos ainda não distantes no tempo carrega o penoso fardo de representificar um 'passado que não passa' e que, em alguns autores, é mesmo aproximado à noção de trauma em toda sua potencialidade de quebra dos nossos horizontes temporais a partir da retomada da cena traumática. A abordagem historiográfica de eventos situados no horizonte de gerações ainda vivas ou 
'nos limites de duração de uma vida humana' foi impulsionada ainda pelas crescentes demandas sociais ligadas aos deveres de memória reivindicados aos diversos grupos sociais que vivenciaram experiências traumáticas, exigindo dos historiadores "uma gestão dos usos sociais e das instrumentalizações da memória ainda não arrefecida, assim como dos passados transformados em história de maneira incompleta"2.

São constantes e bem conhecidos os apelos públicos e midiáticos em torno da necessidade da lembrança, do não apagamento dos rastros e da valorização do passado como patrimônio. Essas formas discursivas reivindicam o vivido sob o signo da memória e, sem dúvida, podemos nos referir ao nosso tempo como aquele em que os direitos de recordação ocupam uma posição central. Essa reiterada necessidade de não esquecer perfaz um distinto arco de manifestações: comemorações, políticas de preservação patrimonial, valorização das vozes sobreviventes do passado, escritas biográficas e autobiográficas, testemunhos, materiais documentais, artísticos e visuais, enfim, uma extensa maquinaria material e simbólica que pode transformar-se, não raro, em 'abuso da memória'.

Como resultante desse diagnóstico da profusão das lembranças e das políticas públicas de preservação de registros do passado, assistimos a uma proliferação de relatos testemunhais que compõe, ao lado de outros gêneros, aquilo que Leonor Arfuch apresentou como "espaço biográfico"3, ou seja, o nosso horizonte escriturário que abriga registros biográficos e autobiográficos, diários, depoimentos, correspondências, blogs. A testemunha, situada nesse diversificado conjunto de narrativas da subjetividade, tem sido tema de um delicado debate a respeito das possibilidades de representação do passado, especialmente no caso de eventos traumáticos, como aqueles relativos às experiências do Holocausto e dos diversos regimes ditatoriais latino-americanos. Esse retorno do 'eu' sob a forma testemunhal tem sido largamente usado como critério de legitimação dos discursos sobre o passado em meio a uma cultura da memória que adquiriu grande visibilidade em nossas sociedades, ainda que possamos lançar dúvidas, conforme Manoel Salgado Guimarães, se este excesso de lembranças produz efetivamente mais conhecimento sobre o passado ou "uma compreensão mais crítica das experiências pretéritas".

Sob o regime presentista, o ato de testemunhar tornou-se um imperativo social dos mais requisitados. François Hartog afirma que "arrastada pela 
agitação subliminar da memória, a testemunha - entendida, por sua vez, como portadora de memória - impôs-se, gradualmente, em nosso espaço público; ela é reconhecida e procurada, além de estar presente e, até mesmo, à primeira vista, onipresente" ${ }^{25}$. Valoriza-se o testemunho pela possibilidade de fornecer, sem desvios interpretativos ou analíticos de terceiros, o acesso imediato ao passado e também por possibilitar, mediante a recuperação de vozes silenciadas pela repressão, a construção de presentes e futuros, evidenciando sua profunda marca política. No regime de historicidade presentista, a imediaticidade da palavra e do corpo parece conferir maior credibilidade ao que é falado e escrito a respeito do passado.

O privilégio do testemunho não significou a elisão "dos problemas que envolvem o ato da lembrança como ato que se realiza sempre e necessariamente a posteriori do acontecido, numa situação vicária à própria experiência

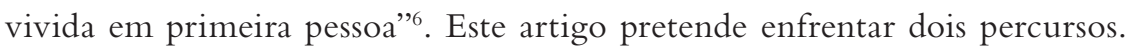
No primeiro, intento demonstrar que, sob a história do tempo presente, o papel do testemunho recuperou sua importância como forma de acesso ao passado. Em seguida, procuro situar criticamente o privilégio epistêmico do testemunho ${ }^{7}$ a partir da tomada de posição a respeito dos limites e alcances da representação historiadora para dar conta das narrativas testemunhais de eventos-limite. A atualidade dessa questão justifica a referência, no título deste artigo, ao conhecido livro organizado por Saul Friedlander sobre as representações do Holocausto.

\section{O testemunho sob o signo do presentismo}

Indagar-se sobre a legitimidade intelectual de uma história do tempo presente pode nos abrir caminho para a interrogação sobre o lugar do testemunho. Lembra-nos Carlos Fico de que uma das características definidoras da história da nossa contemporaneidade é a possibilidade de o conhecimento histórico "ser confrontado pelo testemunho dos que viveram os fenômenos que buscam narrar e/ou explicar"s. Essa distinção decorre de uma situação particular, na qual sujeito e objeto estão imersos em uma mesma temporalidade que pode ser pensada sob a ótica de um passado que resiste à diferenciação em relação ao passado e que parece, sob esse aspecto, não passar. Paradoxalmente, como atesta Temístocles Cézar, há também um presente 
cada vez mais dilatado, que também não passa e cujo significante historiográfico é exatamente a história do tempo presente. ${ }^{9}$

$\mathrm{Na}$ tradição cientificista da história, admitia-se que o caráter distorcido, fragmentado e isolado do relato de um indivíduo impedia que uma declaração dessa natureza funcionasse como representativa de um acontecimento ou de uma experiência vivida. Ranke desfechou um duro golpe contra a possibilidade de uma história do tempo presente que se fundasse na figura privilegiada do testemunho. A necessária objetividade do conhecimento histórico só poderia ser atingida caso o historiador se colocasse o mais distante possível dos acontecimentos, deixando de ser, portanto, testemunha dos eventos do passado. O olhar do historiador e sua atenção aos fatos do seu tempo deixavam de ser indícios seguros para a prova documental e tornavam-se demonstrações de parcialidade e envolvimento emocional. O testemunho só poderia ter algum valor heurístico para a investigação histórica se se submetesse ao jugo dos documentos escritos, sobretudo aqueles de natureza oficial. A desconfiança crítica dos historiadores perduraria ao longo do século XX, mesmo com a recuperação da figura testemunhal em abordagens mais recentes. Dois breves exemplos são esclarecedores. Em 1981, Lucy Dawidowicz exprimia uma visão que era compartilhada por diversos de seus pares, quando afirmava, sem meios cuidados, que "as transcrições dos testemunhos que examinei são repletos de erros de datas, de nomes de pessoas e de lugares (...) e estes depoimentos podem mais desviar o pesquisador desatento do que lhes ser útil" ${ }^{10}$. Já o Dictionary of Concepts in History, organizado, em 1986, por H. Ritter, não traz nenhum verbete para 'testemunho'.

O desencaixe entre passado e presente era condição para que a historiografia do século XIX afirmasse sua competência científica e assegurasse um conhecimento fidedigno da experiência humana no tempo. Em seus ataques ao subjetivismo, Ranke pretendia criticar a concepção de que a história obedece a algum fim moral ou que estabelece diretrizes e regras para o futuro. $\mathrm{O}$ projeto escriturário da historiografia dos oitocentos ancorava-se, desse modo, numa anulação das questões contemporâneas e, por conseguinte, do papel do historiador como agente capaz de intervir diretamente no discurso da história.

Eu gostaria, de alguma forma, de apagar o meu eu e deixar somente as coisas falarem e fazer aparecer as forças poderosas que, surgidas 
e intensificadas, dirigiram-se uma contra outra em uma luta sangrenta e terrível, mas que traziam em si a solução dos problemas mais essenciais do mundo europeu (...) Acontece frequentemente que analogias fugazes induzem ao erro o historiador que tem a intenção de continuar em contato com o presente, bem como o político que insiste em se prender no passado. A musa da história tem o horizonte mais vasto e toda a aptidão em afirmar e em manter a sua opinião, mas manifesta, em seu trabalho, uma consciência cuidadosa ao extremo, e ela parece ciumenta de sua missão. Introduzir, no trabalho histórico, preocupações que pertencem ao presente tem, geralmente, como consequência entravar o livre desenvolvimento desse trabalho. ${ }^{11}$

O esvaziamento da personalidade do historiador tinha como corolário uma ruptura temporal clara, opondo visceralmente passado e presente e demarcando um lugar definido sobre o qual a inquirição das experiências pretéritas se localizaria. Esse lugar deveria ser ocupado por aquele tipo de historiador capaz de se afastar de seu interesse por seu próprio tempo, evitando, dessa forma, que recaiam sobre ele suspeitas de envolvimento e tendenciosidade. Tal preocupação era também a de Fustel de Coulanges, para quem o nosso olhar sobre o presente era sempre condicionado por interesses, preconceitos e paixões. "Compreendemos melhor os acontecimentos e revoluções dos quais nada temos a temer nem nada a esperar", dizia. ${ }^{12}$ Em sucessivas oportunidades, esse notável historiador reafirmou que o passado era a única força à qual o historiador deveria se dedicar, ainda que mediante um grande esforço de anulação das próprias convicções e visões de mundo.

Não é que se possa exigir dele que, no seu íntimo, seja desprovido de opiniões pessoais, sem nenhum tipo de preferências, sem crenças, sem patriotismos. Mas é necessário que ele tenha bastante força de espírito e bastante independência em relação a si mesmo para que, no momento do seu trabalho, no momento em que procura a verdade histórica, aja como se não tivesse nem opinião política nem crenças pessoais, nem mesmo patriotismo. ${ }^{13}$ 
O resgate do papel do testemunho acompanhou de perto o crescimento das pesquisas e investigações sobre temas recentes, delimitando o campo da chamada história do tempo presente. As definições a respeito dos conceitos, recortes e métodos dessa prática historiográfica são distintas, mas convergem em um ponto essencial: a superação do corte radical entre passado e presente que caracterizou a pesquisa histórica ao longo do século XIX e que, como visto, deslegitimava o relato testemunhal. A possibilidade de recorrer aos testemunhos orais era um dos pressupostos da criação do Institut d'histoire $d u$ temps présent (IHTP), em 1979, no interior do Centre National de la Recherche Scientifique (CNRS). O Institut, em realidade, consolidou, com maiores impactos junto à comunidade dos historiadores, uma prática de pesquisa que remontava ao final da I Guerra Mundial e que se relacionava ao propósito de preservar a memórias das atrocidades produzidas pelos estados beligerantes. O propósito de afirmar o presente como um objeto de pesquisa que poderia repousar em bases científicas encontrava reações, mesmo nos anos 80, por parte de renomados historiadores que repetiam os princípios, herdados do século XIX, que interditaram o estudo de tempos recentes. Em um texto publicado originalmente em 1981, Edoardo Grendi reafirmava a antiga censura à história contemporânea.

A história contemporânea é, pelas próprias características do seu objeto, atravessada, mais do que qualquer outra, pelas várias perspectivas das ciências sociais e pela miríade de interrogações da consciência presente. É paradoxal, portanto, que ao menos na Itália ela se apresente como a mais repetitiva e a menos inovadora. Isso nos faz pensar que o historiador da idade contemporânea parte de um sistema conceitual de certezas quase absolutas e considera o trabalho histórico não como uma operação analítica capaz de descobrir nexos significativos e propor interpretações, mas como uma operação política subordinada às suas certezas teóricas e, assim, uma interpretação geral e preconcebida que será sustentada ou, no máximo, enriquecida. ${ }^{14}$

A história do tempo presente, articulada a partir das experiências e testemunhos dos contemporâneos, esforçou-se para assegurar, em termos teóricos e metodológicos, sua presença em face do crescimento, ao longo do século XX, 
das investigações realizadas por jornalistas. As dificuldades de estabelecimento de marcos definidos a respeito do que considerar como 'tempo presente' não escaparam aos seus diversos praticantes ${ }^{15}$. Enquanto alguns, como o historiador alemão Fritz Ernst, reivindicavam periodizações mais convencionais (como a II Guerra Mundial), outros apostavam em características mais peculiares ao século XX, como o Holocausto, as experiências traumáticas de ditaduras ou genocídios ou a possibilidade de utilização de relatos testemunhais. Para Maria Inés Mudrovcic, a história do tempo presente - ou história do passado recente - se define como "aquela historiografia que tem por objeto acontecimentos ou fenômenos sociais que constituem recordações de ao menos uma das três gerações que compartilham um mesmo presente histórico" ${ }^{16}$. Assim, o presente é temporalmente demarcado pela interseção de espaços de experiência das gerações que se solapam. François Bédarida recordava que a proposta do Institut foi “de considerar como 'tempo presente' o tempo da experiência vivida. Retomamos, desse modo, o verdadeiro sentido do termo 'história contemporânea', a saber: a experiência da contemporaneidade" ${ }^{17}$.

Um aspecto comum a essas distintas abordagens sobre o que pode constituir a experiência do tempo presente é a centralidade conferida à questão da memória. Essa proeminência da recordação apresenta-se, não raramente, como um imperativo de ordem ético-política, um dever diante da sucessão de eventos trágicos que marcaram a experiência histórica do século XX. É, ainda, nos termos de François Hartog, um sintoma do presentismo, ou seja, de um regime de historicidade em que o alargamento da categoria do presente parece subsumir nossas formas de percepção do tempo. Escreve Hartog que "este presente, já inquieto, descobriu-se em busca de raízes e de identidades, preocupado com a memória e as genealogias. [...] Como se se desejasse preservar, e de fato reconstituir, um passado já desaparecido ou a ponto de apagar-se". ${ }^{18}$

Como evento-síntese das barbáries genocidas do século XX, o Holocausto impôs à historiografia e à memória o seu lugar como tema indispensável para a reflexão sobre outras histórias traumáticas marcadas pela violência e extermínio, transformando-se, desse modo, em um índice para as representações sobre as relações entre passado e presente, pois,

como experiência-limite, o Holocausto serve para reforçar uma qualidade genérica da interpretação que torna presente o passado, como 
exemplo do lado sombrio da história, das trevas do sentido histórico, do caráter ruinoso do prolongamento temporal do passado até o presente. O Holocausto representa, pois, uma qualidade da experiência na relação temporal tensa entre passado e presente, a ser devidamente levada em conta por um tipo apropriado de constituição de narrativa de sentido. ${ }^{19}$

A emergência do Holocausto como uma espécie de paradigma a partir do qual se interpretam, analisam e se constituem as representações de outras violências estatais e genocídios tem, por certo, os seus riscos e perigos. Enzo Traverso defende o ponto de vista de que um excesso de fetichização da memória desse evento traumático pode produzir uma espécie de religião civil do mundo ocidental. A transformação do Holocausto nessa categoria de memória das atrocidades do século XX relaciona-se a uma mudança decisiva: de acontecimento pouco refletido - em 1946, Sartre publicou suas Reflexões sobre a questão judia sem realizar qualquer menção aos campos de concentração -, o extermínio de judeus torna-se o objeto de uma intensa produção memorialística que funciona como um imperativo ético-político que pretende fazer com que a barbárie não se repita. O julgamento de Eichman assinalou um acontecimento que demarcou precisamente essa mudança, pois, além de representar um juízo do regime nazista como um todo, teve um enorme impacto ao expor, pela primeira vez, as vozes dos sobreviventes que puderam dar testemunho público do sofrimento que estava interiorizado por anos e anos. ${ }^{20}$

Sem deixar de levar em conta os problemas envolvidos em um excesso de apropriação do Holocausto como índice das violências estatais do século XX e de outros eventos-limite, a experiência traumática dos campos de concentração construiu, como recorda Annete Wieviorka, o paradigma do ato de testemunhar, que vale tanto para o que ocorreu quanto para os eventos que ainda se desenvolvem sob nossos olhares. São conhecidas as interseções, especialmente no campo jurídico, entre os usos dos testemunhos do Holocausto e dos sobreviventes das ditaduras latino-americanas. A Soah se situa na fronteira entre a experiência e os discursos e põe à prova não "apenas os limites da representação sob suas formas narrativas e retóricas, mas todo o empreendimento de escrita da história". ${ }^{21}$ 


\section{Os dilemas da representação}

As palavras de Antelme que abrem este artigo postulam o dilema central de todo relato testemunhal acerca de passados traumáticos: a sua simultânea necessidade e impossibilidade ou aquilo que se pode chamar de 'paradoxo da atestação' ${ }^{\prime 2}$. Abre-se então uma fenda entre evento e linguagem, entre o dado inimaginável da experiência e o maquinário linguístico disponível para representá- $\mathrm{la}^{23}$. A realidade traumática parece resistente aos exercícios de sua representação através da memória e dos relatos daqueles que viveram seus mais terríveis momentos, e as tentativas de escrita ou narrativa dos eventos-limite se tornam, no mais das vezes, indícios de uma desconfiança em relação ao próprio testemunho, como aponta Paul Ricoeur:

É por isso que se pode falar de crise do testemunho. Para ser recebido, um testemunho deve ser apropriado, quer dizer, despojado tanto quanto possível da estranheza absoluta que o horror engendra. Essa condição drástica não é satisfeita no caso dos testemunhos dos que se salvaram. Uma razão suplementar da dificuldade de comunicar deve-se ao fato de que a testemunha não esteve ela mesma diante dos acontecimentos; ela não 'assistiu' a eles; ela mal foi um agente, um ator; ela foi vítima. ${ }^{24}$

Em sua filiação etimológica, havia dois termos, em latim, para designar a testemunha. Ela poderia ser aquela que se impõe como um 'terceiro' (terstis) em um contencioso em que dois personagens estão envolvidos. É, tradicionalmente, a versão jurídica do termo. Mas a testemunha também pode ser descrita como superstes, ou seja, aquele indivíduo que atravessou um evento e pode, portanto, dar testemunho dele. Aqui o termo equivale ao sobrevivente de uma experiência. Esses dois significados são derivados do latim. Roberto Vecchi, entretanto, menciona outra tradição, a grega, pouco lembrada quando nos detemos no sentido de testemunha. Aqui, ela é martis, ou seja, mártir, do qual foi derivado o termo martirium, que remete à perseguição sofrida pelos cristãos que testemunhavam sua fé. Martis se origina de um verbo que significa recordar. Esse conjunto de significados se apresenta sob o predomínio da perspectiva memorialística. Excetuando o 
caráter jurídico de terstis, os outros dois sentidos "fornecem uma definição bastante clara da área semântica da testemunha: o sobrevivente que não pode não recordar". ${ }^{25}$

Para Giorgio Agamben, por outro lado, não temos a possibilidade de penetrar na análise interna semântica do texto testemunhal, o que deverá levar o historiador a pensar o lugar do testemunho, ou seja, a consideração do ato do discurso em si, de sua enunciação.

Tomar realmente a sério o enunciado eu falo significa deixar de pensar a linguagem como comunicação de um sentido ou de uma verdade por parte de um sujeito que é seu titular e seu responsável; significa, sim, passar a considerar o discurso no seu puro fato de ter lugar [...] A enunciação assinala, na linguagem, o limiar entre um dentro e um fora, o fato de ter lugar como exterioridade pura. ${ }^{26}$

Sob a investigação que privilegia a enunciação como ato, torna-se pertinente a indagação a respeito da posição do sujeito diante de uma dessubjetivação. A semântica da enunciação parece carregar, nesse aspecto, uma dificuldade intrínseca: por não se ancorar em significados, mas sobre o acontecimento da linguagem, o sujeito não pode tomar a si mesmo como objeto, não pode enunciar-se. É na busca pela recuperação desse lugar do sujeito que Agamben inscreve o seu conceito de testemunho como sendo o sistema de relações entre o dentro e o fora da língua, entre o que pode ser dito e o indizível, entre uma possibilidade e uma impossibilidade de dizer. É nessa cisão entre uma potência e uma impotência que o sujeito deve ser inserido. A pergunta fundamental se torna: de que maneira pode ser atestada, como tal, uma possibilidade de dizer? De acordo com o filósofo italiano:

Precisamente porque o testemunho é a relação entre uma possibilidade de dizer e o fato de ter lugar, ele só pode acontecer por meio da relação com uma impossibilidade de dizer, ou seja, unicamente como contingência, como um poder não-ser. ${ }^{27}$

Esses padrões de cisões são profunda e irremediavelmente destituídos em Auschwitz, "a experiência devastadora na qual se faz com o que o impossível 
seja introduzido à força do real". ${ }^{28}$ Daí a conclusão da impossibilidade plena do testemunho, pois apenas o polo da necessidade absoluta passa a subsistir. A experiência traumática "define um experimento biopolítico sobre os operadores do ser, que transforma e desarticula o sujeito até um ponto-limite no qual o nexo entre a subjetivação e a dessubjetivação parece romper-se". ${ }^{29} \mathrm{O}$ sujeito do testemunho é um sujeito cindido, só adquirindo consistência na desconexão e na separação e, por isso, é o sujeito que dá testemunho dessa dessubjetivação. No campo de concentração, a testemunha e o muçulmano apresentam uma inquebrantável intimidade. A impossibilidade do testemunho foi levada mais adiante por Primo Levi:

Nós, os sobreviventes, não somos as verdadeiras testemunhas [...] mas eles, os muçulmanos, os náufragos, é que são as testemunhas integrais, aqueles cujo depoimento teria uma significação geral. A destruição conduzida a seu termo, ninguém teria subsistido para narrá-la, como ninguém nunca voltou para narrar a sua própria morte. ${ }^{30}$

Nos distintos usos do testemunho - na esfera do cotidiano, dos processos judiciais ou do arquivamento histórico -, a questão de sua confiabilidade é posta logo de início. O ponto de partida é assegurado pelo caráter sensorial e corporal da presença. Requer-se, como indício de verdade, que algo tenha sido visto ou ouvido e que o relato que se faz de um evento ou de um conjunto de eventos obedeça a esse critério de confiabilidade. Mas as condições de produção do discurso do que se viu ou ouviu não asseguram o sentido do gênero testemunhal. É necessário que o receptor acredite nessa capacidade cognitiva do outro. Forja-se um pacto, pois "se a testemunha pretende enunciar a verdade, se está comprometida moralmente, também o interlocutor há de receber com confiança as palavras, há de fiar-se, abandonar-se a um tipo de boa-fé básica, acolhendo a verdade de outrem". ${ }^{31}$

O testemunho só pode assumir sua intenção constituinte de verdade se for transmutado em ato narrativo, em discurso organizador daquilo que foi visto objetivamente. Graças ao que é contado, o mundo ausente torna-se disponível. Isso supõe, como assinalado, uma comunidade de certezas, ou seja, a mutualidade entre quem enuncia o testemunho e aquele a quem se destina. Por outro lado, nem todas as testemunhas são críveis e nem todas as narrativas 
são prontamente aceitas. Todo ato de testemunha é seguido de certos rituais de exposição, de certas marcas distintivas que envolvem gestos, entonações e movimentos. Essas marcas denotam a necessidade do convencimento, pois, em última instância, o testemunho não é prova definitiva e sempre necessita de um "reforço certificador" 32 . É obra inacabada, aberta a outras subjetividades. A crença na veracidade do testemunho é resultante de uma postura política, vital para a ação, na medida em que toma a narração como pressuposto para o que deve ser feito posteriormente. A escolha estilística é um recurso essencial para que o testemunho assuma sua integral legitimidade diante da audiência, reforçando o seu estatuto moral-epistemológico. Levar em conta o caráter performativo de toda atestação implica a admissão pelo historiador de que o seu papel em relação ao testemunho não poderá ser o de um mero exumador da veracidade ou falsidade dos relatos. Nesse plano, é também um indício do testemunho a possibilidade de colocar na mesma balança a desconfiança que, como aponta Paul Ricoeur, "se desdobra ao longo de uma cadeia de operações que têm início no nível da percepção da cena vivida, continua no da retenção da lembrança, para se concentrar na fase declarativa e narrativa de reconstituição dos traços do acontecimento" 33 . ${ }^{34}$

O imperativo da suspeita e da colocação em prova dos relatos inscritos em primeira pessoa traduz o dilema central em relação aos discursos testemunhais como parte da produção de narrativas sobre o passado: eles podem funcionar como uma representação histórica efetiva do vivido? Em que medida o trabalho crítico do historiador, com seu escrutínio metodológico, não interfere indevidamente nesses relatos, que devem, em última instância, oferecer um acesso direto ao passado? Interpor uma desconfiança crítica em relação à voz da testemunha não pode significar um descuido ético? O testemunho deve ser dotado de algum estatuto epistemológico privilegiado em nossa relação com os chamados eventos-limite? Tais eventos, por sua carga de excepcionalidade e terror, podem ser apreendidos a partir de nossas convencionais técnicas de narração historiográfica?

O conhecido trabalho de Saul Friedlander buscou enfrentar essas questões e discutir os limites da representação de eventos traumáticos. Sua tese, largamente conhecida, é que o Holocausto, como o caso extremo de extermínio em massa, resiste às formas tradicionalmente disponíveis para representar o passado. A magnitude desse evento, o 'superlativo da História' ${ }^{35}$, torna 
suspeitas as tentativas de reduzi-lo ao meramente discursivo e demanda uma certa 'pretensão de verdade' ${ }^{36}$. Friedlander tem em mente, em especial, certas formulações relativistas que consagraram o exame dos tropos literários como o critério de crítica das representações históricas. Enfrentar os perigos do relativismo fornece, ainda, um critério ético para o exame dos testemunhos do Holocausto, transcendendo à clara função cognitiva desses relatos.

Pareceria óbvio que uma manifestação tão monstruosa do "potencial humano" não poderia ser esquecida ou reprimida. Se a isto se soma que os seus autores inverteram esforços consideráveis não somente em dissimular, mas em borrar todos os rastros de suas ações, a obrigação de dar testemunho e registrar o passado resulta ainda mais premente. Este postulado implica, muito logicamente, a ideia imprecisa - mas não por isso menos óbvia - de que dito registro não deve ser banalizado ou distorcido por representações grosseiramente inapropriadas. ${ }^{37}$

Embora possa ser trivial considerar que o testemunho é registro documental de uma experiência, seu uso como forma de acesso privilegiado ao passado situa a narrativa testemunhal como o limite para que qualquer reconstrução dos fatos seja possível. Estabelece-se um ponto de ruptura entre o registro factual dos acontecimentos e a representação feita pelo historiador, esta entendida como uma distorção da verdade do testemunho. No regime presentista ou na 'era do testemunho', portanto, a palavra da testemunha pode ser obliterada ao se transformar em conteúdo de uma representação histórica. O discurso do historiador introduz uma mediação entre os que viveram a experiência-limite e aqueles que não viveram, e por isso o testemunho é a única linguagem em que os acontecimentos devem ser representados, pois "o testemunho nos dá uma representação das experiências mais significativas e profundas de uma pessoa". ${ }^{38}$

Para Ankersmit, uma das falhas dos usuais modos de representação histórica do Holocausto reside na ausência de um relato expressivo da experiência dos homens que vivenciaram esse acontecimento traumático. Esse limite só pode ser superado pela adoção da linguagem pura do testemunho como o único modo de dar expressão à experiência e reexperiência do Holocausto. ${ }^{39}$ 
Apenas a linguagem testemunhal, sem desvios ou distorções, pode exprimir as vivências mais profundas daqueles que passaram pelos horrores do genocídio. Ela confronta, através da fala direta, a objetividade do discurso historiográfico e sua pretensa moralidade neutra. A linha entre a voz da testemunha e nós coloca a historiografia em seu próprio contexto e desnuda todos os seus limites, pois "a linguagem do testemunho vai mais além das limitações da linguagem narrativa que o historiador costuma usar, na qual uma voz impessoal, intersubjetiva interpela uma audiência igualmente impessoal e intersubjetiva". ${ }^{40}$

Os componentes do testemunho não são discerníveis em seus aspectos verídicos ou falsos ou em seus elementos de sentido. Para Ankersmit, a totalidade do testemunho se refere ao passado. Não há protocolos, esquemas ou normas éticas que permitam, a priori, avaliar seu êxito, e os critérios de decisão são de tipo estético, o que supõe que esse tipo de relato, como representação, não pode ser confrontado em si mesmo, mas com as demais representações rivais. $\mathrm{O}$ ato de testemunhar aponta para o momento em que a experiência traumática se torna revivida e, nesse sentido, apaga-se a barreira que separa a linguagem da realidade, a ponto de esta assumir a forma de um testemunho. Como presença sem mediação alguma de uma experiência, o testemunho adquire centralidade em nosso regime de historicidade presentista. Esteban Lytthgoe demonstrou que, ao se indagar sobre quais conteúdos ficaram de fora nos atuais debates sobre a representação do Holocausto, Ankersmit admitia uma separação entre conteúdo e forma que não encontrava paralelo na totalidade de sua obra ${ }^{41}$. Esse equívoco teria origem em uma proposição inapropriada dos termos do debate. Para Lytghoe, as vozes dos sobreviventes são inadequadas para representar, de forma respeitosa, acontecimentos-limite. Faltam os testemunhos daqueles que experimentaram a tragédia do Holocausto em sua integridade, ou seja, dos que padeceram nos campos de concentração. Os contornos da tese dos eventos sem testemunhos já foram aqui apontados. Para o restante da argumentação desenvolvida neste artigo, é importante ressaltar a insuficiência teórica dessa noção da impossibilidade de representação por ausência de testemunhas 'plenas', pois o testemunho não significa apenas o relato da experiência daqueles que vivenciaram completamente os acontecimentos, mas também dos que lá estiveram, ainda que suas narrativas sejam carregadas de limites e lacunas. Por outro lado, a crítica 
de Lythgoe, recuperada de Domick Lacapra, ao uso indistinto da noção de trauma, que pode colocar em pé de igualdade perpetradores e vítimas - uma vez que a experiência traumática pode ser vivenciada por ambos -, é bastante pertinente e levanta o problema do uso de categorias do presente para se referir a acontecimentos passados.

Como prova do ocorrido, como acesso não mediado ao passado ou mesmo como representação histórica, o testemunho inscreve-se em um regime do arquivo e funciona como uma resposta ao desejo dos perpetradores de dissipação dos acontecimentos. É igualmente o momento em que a "literatura deve afastar-se e ceder o seu lugar quando o testemunho é assim posto em comunicação direta com a verdade histórica, pelo viés do que é narrado e, portanto, pelo viés da experiência pura, sem outro intermediário" ${ }^{2}$. A lei do arquivo anula qualquer outra forma de representação que não seja aquela revelada pela literalidade do testemunho. Os testemunhos só podem ser lidos como documentos e às vítimas resta apenas a tarefa de fornecer as provas.

Obviamente, este arquivamento do testemunho é induzido e imposto pelo próprio acontecimento, pela estrutura do acontecimento. Um acontecimento não é um fato. A vontade genocidiária é, por excelência, a que anula, no cerne mesmo do acontecimento, a facticidade do fato. Portanto, é a que obriga, no mais alto grau, a vítima a fornecer a prova. Nessa matriz, nesse momento originário em que o testemunho se transforma em prova, a vítima "sabe" que a máquina genocidiária pela qual foi esmagada buscava destruir a própria noção de fato. Essa destruição vale para todos, para o carrasco e a vítima, assim como para a humanidade civilizada. ${ }^{43}$.

Decorre desse imperativo documental do testemunho a impossibilidade de toda literatura. Para Nichian, entretanto, escapar da lei do arquivo não significa que o testemunho possa fornecer alguma modalidade de representação da catástrofe. Esta segue sendo irrepresentável. O que pode ser narrado é essa própria impossibilidade. Sendo o trauma representável ou não, o dilema parece persistir e desafiar os historiadores: os testemunhos pretendem narrar algo a respeito de experiências marcadas por situações de extremo desespero e dor. O que deve ser feito com esses relatos? A simples admissão de seu 
caráter documental, de sua função produtora da prova não significa assumir, de algum modo, a perspectiva da eliminação do fato tão cara aos perpetradores? Por que os testemunhos devem ser confinados à lei do arquivo? É possível forjar uma poética do testemunho que leve em conta a tênue linha entre arte e história? Advertindo-nos em relação aos distintos sentidos que o testemunho pode assumir para o historiador e para aqueles que foram os seus produtores, Enzo Traverso assinala que

ali onde o historiador não vê mais do que uma etapa de um processo, um detalhe em um quadro complexo e em movimento, a testemunha pode captar um acontecimento crucial, a virada de uma vida. $\mathrm{O}$ historiador pode decifrar, analisar e explicar as fotos conservadas do campo de Auschwitz. Sabe que são judeus os que descem do trem, sabe que os SS que os observam participaram de uma seleção e que a grande maioria das figuras desta foto não tem mais do que umas horas de vida. A uma testemunha, esta foto dirá muito mais. Ela recordará sensações, emoções, ruídos, vozes, odores, o medo e o estranhamento da chegada ao campo, o cansaço de uma longa viagem realizada em condições horríveis; dito de outro modo, um conjunto de imagens e recordações completamente singulares e completamente inacessíveis para o historiador. Este último pode acercar-se tão somente sobre a base de um relato a posteriori, origem de uma empatia comparável a que experimenta o espectador de um filme e não a que sente a testemunha. ${ }^{44}$

Tal dissociação entre memória e história pode converter o historiador em um simples organizador dos testemunhos, emprestando-lhes um estatuto privilegiado de acesso ao passado, uma via preferencial para o conhecimento sobre experiências eivadas de tragicidade? Qualquer tipo de interrogação metódica representa, a priori, uma distorção do testemunho e, o que é mais perigoso, um desvio ético do historiador? Os testemunhos devem permanecer em estado bruto, como atestação do ocorrido, como prova documental da experiência passada?

Parto de uma rejeição tanto da ideia de que o testemunho fornece uma representação privilegiada e direta das experiências vividas (Ankersmit) 
quanto da tese de que os relatos de testemunhas de eventos-limite apresentam interdições quase insuperáveis à representação historiadora (Friedlander). Esses dois pontos de vista conferem ao estatuto um caráter epistêmico privilegiado como forma de acesso imediato àquilo que foi presenciado. Por outro lado, os historiadores que tomam os testemunhos como fontes de informação sobre o passado carregam uma justificada desconfiança metódica sobre sua confiabilidade a ponto de poder descartá-los completamente. A importância dos testemunhos, aponta Dominick Lacapra, se faz mais evidente "quando se pensa em que apontam algo que não é idêntico ao conhecimento puramente documental" ${ }^{45}$. Dando forma à experiência, o testemunho deve ser compreendido a partir das memórias, lacunas e esquecimentos em que incorre a fim de se ajustar ao passado, negá-lo ou reprimi-lo. Além disso, algumas das mais significativas obras da chamada 'literatura de testemunho' desmentem, segundo Verónica Tozzi, a tese de que esses relatos são irrepresentáveis ${ }^{46}$. Torná-las inabordáveis é, acima de tudo, ser injusto com tais obras. Os apelos em torno da necessidade de escutar as vozes daqueles que atravessaram uma experiência-limite não são novos e eles estão na raiz dos estudos sobre trauma, das políticas de identidade e do pós-colonialismo. Por outro lado, são constantes os sinais de desconfiança em relação à historiografia tradicional que, em seu afã de produzir interpretações compreensivas com o propósito de alcançar a máxima objetividade, tem sido cúmplice na distorção ou silenciamento das experiências dos sujeitos vítimas da opressão ou da postergação. A representação historiadora corre o risco, ainda, de naturalizar ou tornar mesmo justificáveis os atos de perpetração, subsumidos na explicação geral dos processos dos quais foram parte. ${ }^{47}$

O privilégio epistêmico situa o testemunho em uma posição que expressa exclusivamente um registro documental e impede que ele participe na arena pública, mediante suas intervenções discursivas, formulando perguntas sobre como dar sentido, como compreender o passado. Se o discurso supõe a literalidade de uma experiência inabordável e irreversível, ao invés de conflitiva e narrativamente construída, interdita-se o diálogo com aqueles que foram impelidos a testemunhar. Suas vozes permanecem inscritas na lei do arquivo, na fria formatação da evidência empírica.

A noção de que os eventos traumáticos são um excesso irrepresentável pode ter outras duas sérias consequências. Colocar acento na 
impossibilidade de representação pode distrair a atenção para o que, de fato, pode e deve ser representado ou reconstruído tão exatamente como seja possível, como, por exemplo, a vida cotidiana das vítimas. A outra é o risco de se construir tais acontecimentos sob o marco de uma estética hiperbólica do sublime, o que pode redundar numa sacralização do evento que induza a uma explicação inadequada não apenas da representação, mas do próprio agenciamento ético. ${ }^{48}$

Qualquer crítica do testemunho é certamente devedora da densa e impactante formulação de Beatriz Sarlo. Como ponto de partida, a autora argentina diagnostica a emergência de uma "cultura da memória" que teria, entre outras consequências, a elevação da narrativa em primeira pessoa como instância de acesso ao passado. As experiências narrativas centradas no 'eu' podem desempenhar o seu papel ético no contexto da reconstrução democrática do pós-ditadura, mas somente ao preço de um apagamento da crítica historiográfica é que essa proliferação de testemunhos pode significar um conhecimento verdadeiro do terrorismo de estado. A crítica de Sarlo, pela forte repercussão de seu 'Tempo passado', é uma referência importante para a discussão em torno dos limites e das representações dos testemunhos.

A suspeita sobre o que Sarlo chama 'retórica testemunhal' está assentada, como bem observa Cláudio Pereira Elmir, sobre uma atitude modernista que reserva à subjetividade uma posição que não contamine a dimensão objetiva do relato. A pureza deste só pode ser conservada mediante uma cisão do sujeito que distribua indiscriminadamente o espaço do 'eu' e o 'espaço do comum'. ${ }^{49}$ Em outras palavras, Sarlo pretende assegurar alguma possibilidade de intervenção metodológica sobre o testemunho, de modo a não deixá-lo em uma "cristalização inabordável", pois, afinal, como discursos que são, as narrativas testemunhais não gozam de qualquer privilégio epistêmico que as torne impermeáveis. ${ }^{50}$

O cerne da argumentação de Sarlo localiza-se em sua avaliação da 'retórica testemunhal', ou seja, das formas de articulação narrativa das experiências das testemunhas e que, de acordo com as interpretações da autora, são responsáveis pelo excesso de confiança na palavra da testemunha - sem contar, obviamente, os aspectos éticos e ideológicos que confluem para a aceitação do que é dito. Os testemunhos se caracterizam por um 'modo realista-romântico' de exposição, cujo primado do detalhe cumpre a ambição de nada deixar

\section{Maracanan}


escapar e assegurar a exatidão. A narrativa em primeira pessoa aponta para a dimensão romântica do relato. Em conjunto, trata-se de produzir um discurso que produza credibilidade a partir da experiência daquele que viveu os acontecimentos e que, portanto, pode contar, em primeira mão, usando a primeira pessoa. Afirma Sarlo que "num testemunho, jamais os detalhes devem parecer falsos, porque o efeito de verdade depende deles, inclusive de sua acumulação e repetição" 51 . A profusão de lembranças e indícios reforça a certificação do relato e a experiência vivida se preenche cada vez mais na e pela figura do narrador.

Assumindo que a crítica metodológica deve ser capaz de romper com a 'fetichização da verdade testemunhal' e com o primado das narrativas em primeira pessoa como lembrança privilegiada do vivido, Sarlo faz menção a um tipo de escrita do testemunho no qual a força da experiência pessoal não se sobrepõe ao registro argumentativo. Ela destaca, como exemplos dessa modalidade, os livros de Emílio de Ípola (La bemba) e de Pilar Calveiro (Poder $y$ desaparición). Nessas obras, os sujeitos são submetidos, na narração, a uma "estrutura de relações exposta conceitualmente" 52 , isto é, as lembranças são organizadas a partir de regras que se situam no campo das Ciências Sociais. Sarlo afirma: "Como se pudessem pôr provisoriamente em suspenso o fato de terem sido vítimas em termos diretos e pessoais da repressão, ambos escreveram com conhecimento disciplinar, tentando se ater às condições metodológicas desse saber" ${ }^{\prime 53}$. Os dois autores, ex-militantes da luta contra a ditadura argentina, distinguem-se por produzir uma abordagem fundada no deliberado silenciamento do eu e no extenso uso de uma linguagem radicada em critérios controlados de verificação.

A bem-vinda crítica de Sarlo representou uma efetiva contribuição para o debate em torno dos testemunhos e alertou os historiadores para os riscos de uma tomada dos relatos em primeira pessoa como documentos capazes de revelar o passado sem quaisquer mediações. Por outro lado, a substituição da retórica testemunhal por uma modalidade narrativa que combine exposição empírica com os protocolos metodológicos das humanidades parece-me um recurso que não aprofunda um ponto central: tanto quanto a escrita em primeira pessoa, a escrita acadêmica apresenta aspectos figurativos que não representam apenas escolhas estéticas, mas, sobretudo, atuam na própria elaboração do passado. Além disso, nos testemunhos de sobreviventes 
de eventos traumáticos, a dimensão ética e a pesada carga emocional são partes integrantes e se relacionam com esforços coletivos fundamentais na reconstrução de ordens sociais democráticas e, sob esse aspecto, as almas do narrador e do cidadão são urgentemente complementares.

Uma das propostas que mais leva adiante o testemunho como narrativa figurada é dada pela "nova epistemologia do testemunho", de Verónica Tozzi. Evitando conceder à testemunha qualquer forma privilegiada de acesso ao ocorrido, a autora rejeita a separação rígida entre história, literatura e memória política na análise das narrativas testemunhais, pois os testemunhos não são uma simples jornada ao passado ou funcionam como prova de eventos ocorridos ${ }^{54}$, mas atuam em sua construção a partir de uma ação no presente e são, desse modo, a mais importante fonte de elaboração do conhecimento sobre esses eventos, mais até do que a própria experiência e a razão.

Essas observações não implicam que as distinções entre relatos estritamente verdadeiros e falsos sejam irrelevantes ou que os critérios de atestação do historiador não tenham qualquer importância. Por outro lado, em uma controvérsia historiográfica, pouco será alcançado se os historiadores se concentrarem exclusivamente em questões de autenticidade ou de verificação dos testemunhos com o fim único de reconstruir o que ocorreu. "Se temos dúvidas específicas", escreve Verónica Tozzi, "nós recorremos aos nossos protocolos de autenticação, mas se nós não temos, devemos interrogar como o testemunho contribui para o trabalho de compreensão" 55 . Para isso, convém ainda reconhecer a importância da linguagem ou do estilo de testemunhar como um componente essencial da legitimidade daquilo que é narrado, tanto sob a ótica de quem testemunha quanto da audiência. Testemunhar é, sobretudo, um ato performativo.

As hipóteses de Tozzi são testadas em sua análise a respeito de três testemunhos de eventos traumáticos. Os trabalhos de Primo Levi, Pilar Calveiro e Victor Kemplerer são examinados a partir de um triplo compromisso que a autora encontra nesses escritos: a negação da impossibilidade de representação; a recusa em emitir um julgamento moral definitivo sobre aqueles que compunham a zona cinzenta entre colaboradores e pessoas comuns; e a aceitação consciente do papel que as decisões estilísticas desempenham na realização de objetivos morais e epistêmicos. O valor desses testemunhos não pode ser localizado a partir da experiência de sobrevivência dos seus autores, mas do "propósito social de comunicação" 56 . A ênfase em um estilo 'científico'

\section{Maracanan}


por parte desses autores pode produzir a pressuposição de um privilégio da dimensão epistêmica dos seus relatos sobre a dimensão política. Para narrar o impronunciável, Levi, Kemplerer e Calveiro valeram-se de seus próprios recursos profissionais de químico, filólogo e sociólogo. Mas a indagação pertinente parece ser outra: a partir desses usos de categorias e linguagens próprias de determinados campos científicos, quais são as implicações públicas pressupostas do papel do testemunho?

O relato traumático-testemunhal, nesse aspecto, se utiliza de figuras de linguagem para transmitir o que é aparentemente não dito ou aquilo que torna esse relato difícil ou impossível. Essas mesmas figuras, entretanto, não são capazes de descrever a experiência em sua totalidade. Isso decorre não apenas em função de o sujeito não poder ser a causa primeira em uma sequência de eventos, mas também pelas limitações da linguagem em oferecer uma completa revelação do passado. ${ }^{57}$ Essas limitações, contudo, não afastam do testemunho a sua tarefa de dizer algo a uma plateia, ainda que o que é transmitido não seja obrigatoriamente 'o que' aconteceu, mas 'que' algo aconteceu.

A instituição do testemunho apresenta-se como uma forma de honrar o informante e aqui se evidencia a estreita relação entre as dimensões morais e epistêmicas. Aceitamos os testemunhos porque estamos de acordo com o fato de que eles narram o insuportável, a dor extrema, e não pelo fato de eles se originarem de uma experiência direta. Esse reconhecimento funda a comunidade e, nesse aspecto, o conhecimento provido do testemunho é um bem coletivo. Negar o testemunho é, portanto, uma forma de desonra e de destruição do conhecimento comunitário. Se considerarmos apenas a acuidade das informações, perderemos de vista a dimensão fundamental do ato de testemunhar, ou seja, a transmissão de sentidos dos eventos narrados. Se considerarmos exclusivamente as informações exibidas, não conseguiremos apreciar com a profundidade exigida os caminhos pelos quais os testemunhos, como instituição, se tornam um bem coletivo. ${ }^{58}$

Usualmente, as escolhas estilísticas das testemunhas são interpretadas como opções entre uma linguagem descritiva ou outra figurativa, isto é, entre recursos que servem para relatar fielmente os eventos e outros que funcionam como meros ornamentos linguísticos. A partir de Hayden White, Tozzi demonstra que o estilo asséptico de Primo Levi foi informado por um 
seletivo uso da Divina Comédia, de Dante, e de outras específicas passagens retiradas de textos classificados como literários. Com isso, pode-se admitir que todo testemunho - mesmo aquele que se apresenta sob a forma de uma narrativa mais austera - é figurativo, e esse aspecto não o torna menos objetivo ou verídico. E para os casos dos três testemunhos analisados por Tozzi, a opção por um estilo científico de abordagem relaciona-se não com seus protocolos de atestação, mas com a possibilidade de oferecer-lhes uma ferramenta que repele seu desconforto com a autoridade de suas experiências como vítimas. ${ }^{59}$

Abandonadas as resistências em considerar os elementos figurativos dos relatos testemunhais como constitutivos tanto dos próprios eventos sobre os quais se pretende falar quanto do conhecimento sobre eles, os testemunhos podem estar mais próximos de um tipo de abordagem pragmática que vincula narrador e audiência em uma rede que articula infinitos atos de testemunho que são, por sua vez, atos performativos que constroem o conhecimento sobre o passado. Dessa forma, o conhecimento é um status ao qual o testemunho pode aspirar na medida em que é constituído em e através de cada testemunho. Essa aproximação aponta para três importantes consequências em relação à natureza e ao papel do testemunho. Em primeiro lugar, o relato da testemunha encontra-se liberto da ideia de que ele é essencialmente uma transmissão sem interpretação e distorção de uma experiência direta. Disso decorre, como segunda consequência, que os sobreviventes de eventos-limite são participantes do esforço coletivo de construção de representações do que ocorreu. Por fim, tal forma de compreender o papel dos testemunhos dirige a atenção para as convenções linguísticas e para seu caráter performativo, características que não podem ser percebidas quando as falas dos sobreviventes estão inscritas na lei do arquivo ou no modelo de atestação jurídica. ${ }^{60}$

A noção de trauma tem sido usada por alguns autores como uma chave explicativa para o problema da representação de eventos-limite. Ao narrar uma experiência vivida em situações de extrema adversidade, a testemunha, em alguma medida, revive os feitos do passado sob o predomínio do trauma. Dominick LaCapra assinala que, em um importante sentido, o que é narrado não é passível de crítica enquanto testemunho de uma experiência tal como ela é recordada e revivida. ${ }^{61}$ A narração do trauma implica a reconstrução de um espaço simbólico e a retomada do fluxo da

\section{Maracanan}


vida, trazendo novamente a testemunha para o mundo presente; não obstante, falando na linguagem da melancolia, pode-se "pensar que algo da cena traumática permanece incorporado, como um corpo estranho, dentro do sobrevivente" ${ }^{2}$. Narrar, nesse sentido, torna-se um imperativo para a busca de elaboração do trauma e, consequentemente, para a restauração dos laços entre passado e presente.

A retomada da vida no presente, através da narrativa que elabora o trauma, implica, segundo Lacapra, o funcionamento consciente da linguagem e um elevado grau de distância crítica e perspectiva, cenário distinto da memória traumática, em que o sobrevivente é assaltado por lembranças compulsivas e o passado é revivido sem controle. A elaboração significa ainda a passagem para uma memória que pode assimilar o resultado da verificação crítica e integrar informação exata como componente de sua validação no espaço público eticamente responsável. Esse tipo de memória cognitivamente precisa é indispensável na construção de uma organização política democrática no presente e no futuro. ${ }^{63}$

A tese da elaboração do trauma como momento constituinte de uma memória testemunhal que admite uma verificação crítica a partir dos critérios de veracidade e falsidade deixa de lado um aspecto que tem sido levantado por diversos testemunhos de sobreviventes de situações traumáticas: o uso da imaginação. Em diversas narrativas, ela funciona como o meio para a reação diante da impossibilidade de testemunhar e é "chamada como arma que deve vir em auxílio do simbólico para enfrentar o buraco negro do real do trauma" ${ }^{64}$. Assim, a experiência traumática encontra na imaginação um meio de se tornar narração, enfim, de ser transmutada em testemunho. Talvez aí esteja a própria possibilidade de existência de uma literatura do testemunho, a partir da introdução da imaginação para suscitar a descrição do inimaginável. As críticas e censuras impostas ao testemunho por conta da imaginação talvez forneçam o ponto de partida para uma radical revisão das relações entre o discurso historiográfico, o literário e o psicanalítico, aproximando-os da vida.

Como uma brevíssima conclusão, podemos nos indagar a respeito das consequências das questões levantadas acima para as experiências presentes que, como a brasileira, ainda aguardam o acerto de contas com um passado traumático que parece não passar. As políticas de memória e os testemunhos 
dos sobreviventes dos horrores do regime ditatorial assumiram reconhecida importância no contexto da transição para a democracia. A revelação das atrocidades passadas torna-se, desse modo, um imperativo social e moral, e sua recepção positiva nas sociedades pós-ditadura atestam a aceitação geral dessa premissa. A narração traumática é sempre um compromisso entre a memória individual e aquela construída pela sociedade. A recordação provocada pelos testemunhos significou, sem dúvida, um aporte importante para a restauração dos laços sociais e comunitários perdidos ou destruídos pela violência do Estado e, ainda, um suporte jurídico para a responsabilização dos seus agentes perpetradores. Poucos ousariam lançar dúvidas sobre a legitimidade - e mesmo sobre a veracidade - dessas vozes. Essa autonomia não sugere que seja inapropriado confrontar a escrita testemunhal com os protocolos do trabalho historiográfico. Para Offenstadt, trata-se de duas ordens de verdade sobre o passado e a oposição radical entre elas não parece encontrar mais, hoje em dia, razão de ser. Ambas, em suas particulares configurações e formas de retenção das experiências pretéritas, inscrevem-se em determinados regimes de verdade. ${ }^{65}$

Ao percorrer alguns caminhos que me levaram à centralidade do papel das escolhas dos estilos de narrativa e dos recursos discursivos, não endossei alguns postulados extremos que minimizam as diferenças entre fatos ocorridos e não ocorridos e a importância dessa distinção para o trabalho de construção do conhecimento sobre o passado. A maquinaria conceitual e metodológica do historiador, após decênios de meticulosa constituição, deverá ter algo a dizer sobre a veracidade do relato. Pouco avançaremos, contudo, se circunscrevermos nosso trabalho na depuração dos fatos ou na detecção de lacunas ou falseamentos nos registros documentais. Perceber os aspectos figurativos do testemunho não desmerece o valor do dito como prova e nem sua necessária dimensão ética. Aceitar que esses testemunhos não sejam a única representação possível de eventos traumáticos alarga as possibilidades de diálogo com homens e mulheres que, se não viveram a experiência das violências estatais em sua plenitude, conseguiram legar relatos dos horrores que presenciaram, permitindo, ainda, perceber, na dinâmica narrativa, a trama sutil em que se entrelaçam o pessoal e o coletivo e, em última instância a possibilidade ou não de se dar conta da própria experiência. 


\section{Notas e Referências}

1 Robert ANTELME. L'espèce humaine. Paris: Gallimard, 1957, p.9.

2 Marieta de Moraes FERREIRA. "Demandas sociais e história do tempo presente”. In: Flávia VARELLA et al. (org.). Tempo presente e usos do passado. Rio de Janeiro: Editora da FGV, 2012, p. 114.

3 Leonor ARFUCH. El espacio biográfico: dilemas de la subjetividad contemporánea. Buenos Aires: Fondo de Cultura Económica, 2010, p. 17.

4 Manoel Luiz Salgado GUIMARÃES. "O presente do passado: as artes de Clio em tempos de memória”. In: Martha ABREU, Rachel SOIHET e Rebeca GONTIJO (orgs.). Cultura política e leituras do passado: historiografia e ensino de história. Rio de Janeiro: Civilização Brasileira, 2007, p. 27.

5 François HARTOG. A testemunha e o historiador. In: Evidência da História: o que os historiadores veem. Belo Horizonte: Autêntica, 2011, p. 284.

6 Manoel Luiz Salgado GUIMARÃES. Op. Cit. p. 37.

7 Verónica TOZZI. "The epistemic and moral role of testimony”. In: History and Theory, 51, 2012, p. 1.

8 Carlos FICO. "História do Tempo Presente: eventos traumáticos e documentos sensíveis: o caso brasileiro”. In: Varia História, v.28, n.47, 2012, p. 44.

9 Temístocles CEZAR. "Tempo presente e usos do passado". In: Flávia VARELLA et al. (org.). Tempo presente e usos do passado. Rio de Janeiro: Editora da FGV, 2012, p. 32.

10 Lucy DAWIDOWICZ. The Holocaust and the historians. Cambridge/Londres: Harvard University Press, 1981, p. 177.

11 Apud Sabina LORIGA. "O eu do historiador". In: História da historiografia, n.10, 2012, pp. 249-50.

12 Apud Carlos FICO. "História do Tempo Presente: eventos traumáticos e documentos sensíveis: o caso brasileiro". In: Varia História, v.28, n.47, 2012, p. 46.

13 Apud François HARTOG. Le XIXe siècle et l'histoire: le cas Fustel de Coulanges. Paris: Editions du Seuil, 2001, p. 360.

14 Edoardo GRENDI. "Micro-análise e História Social”. In:, Mônica Ribeiro de OLIVEIRA \& Carla Maria de Carvalho ALMEIDA (orgs.). Exercícios de micro-história. Rio de Janeiro: FGV, 2009, p. 38. 
15 Carlos FICO. "História do Tempo Presente: eventos traumáticos e documentos sensíveis: o caso brasileiro”. In: Varia História, v.28, n.47, 2012, pp. 72-74.

16 Maria Inés MUDROVCIC. "El debate em torno a la representación de acontecimientos límite del pasado: alcance del testimonio como fuente". In: Dianoia, v.LII, n.59, 2007, p. 128.

17 François BÉDARIDA. Histoire, critique e responsabilité. Bruxelas: Complexe, 2003, p. 64.

18 François HARTOG. Régimes d'historicité: presentism et expériences du temps. Paris: Le Seuil, 2003, p. 15.

19 Jorn RUSEN. Razão histórica. Teoria da história: os fundamentos da ciência histórica. Brasília: Editora da UNB, 2001, p. 171-2.

20 Enzo TRAVERSO. "Memoria, olvido, reconciliación: el uso público del pasado. In: Jorge CERNADAS e Daniel LVOVICH (eds.). História, ¿para qué?: revisitas a uma vieja pregunta. Buenos Aires: Prometeu Libros, 2010, p. 52-4.

21 Paul RICOEUR. A memória, a história, o esquecimento. Campinas: Editora da UNICAMP, 2007, p. 267.

22 Verónica TOZZI. "The epistemic and moral role of testimony”. In: History and Theory, 51, 2012, p. 5.

23 Márcio SELIGMANN-SILVA. "Narrar o trauma: a questão dos testemunhos de catástrofes históricas". In: Psicologia Clínica, v.20, n1, 2008, p. 47.

24 Paul RICOEUR. A memória, a história, o esquecimento. Campinas: Editora da UNICAMP, 2007, p. 187.

25 Roberto VECCHI. "Barbárie e representação: o silêncio da testemunha". In: Sandra Jatahy PESAVENTO (org.). Fronteiras do milênio. Porto Alegre: Editora da UFRGS, 2001, p. 78.

26 Giorgio AGAMBEN. O que resta de Auschwitz. São Paulo: Boitempo, 2008, p. 142.

27 Idem, p. 147.

28 Idem, p. 149.

29 Idem, ibdem.

30 Apud François HARTOG. A testemunha e o historiador. In: Evidência da História: o que os historiadores veem. Belo Horizonte: Autêntica, 2011, p. 211. 
31 Fernando KOLLERITZ. "Testemunho, juízo político e história”. Revista Brasileira de História, v.24, n.48, 2004, p. 74.

32 Idem, p. 77.

33 Paul RICOEUR. A memória, a história, o esquecimento. Campinas: Editora da UNICAMP, 2007, p. 171.

34 A desconfiança em relação à fala testemunhal fundamenta alguns experimentos no âmbito da psicologia judiciária. Diz-nos Ricoeur sobre um desses testes: "uma das provas básicas consiste na tarefa imposta a uma corte de indivíduos de produzir uma reconstituição verbal da mesma cena filmada. O teste supostamente permite medir a confiabilidade do espírito humano no que diz respeito às operações propostas, seja no momento da percepção, seja na fase de retenção, seja, enfim, no momento da reconstituição verbal. O artifício deste teste sobre o qual importa chamar a atenção está em que o experimentador é quem define as condições da prova e valida o estatuto da realidade do fato a ser atestado: esse estatuto é considerado como adquirido na própria montagem do experimento. São então os desvios em relação a essa realidade comprovada pelo experimento que são levados em consideração e medidos. O modelo implícito nessa pressuposição é a confiabilidade indiscutível do olho da câmera. Certamente, os resultados dos experimentos não devem ser desprezados: dizem respeito à presença flagrante de distorções entre a realidade conhecida por outros meios e os depoimentos dos sujeitos de laboratório. Para nós, a questão não é submeter à crítica as conclusões da investigação a respeito da desqualificação do testemunho em geral, mas de questionar, por um lado, aquilo que Dulong denomina o 'paradigma do registro', a saber, a câmera, e por outro lado a ideia do 'observador isento', preconceito ao qual estão submetidos os sujeitos do experimento". (Paul RICOEUR. A memória, a história, o esquecimento. Campinas: Editora da UNICAMP, 2007, p. 171)

35 Márcio SELIGMANN-SILVA. "A história como trauma". In: Arthur NESTROVSKI e Márcio SELIGMANN-SILVA (orgs.). Catástrofe e representação. São Paulo: Escuta, 2000, p.77.

36 Saul FRIEDLANDER. "Introdución". In: Saul FRIEDLANDER (org.). Em torno a los limites de la representación: el nazismo y la solución final. Bernal: Univ. Nacional de Quilmes, 2007, p. 24.

37 Idem, ibdem. 
38 F.R. ANKERSMIT. Historical Representation. Stanford: Stanford University Press, 2001, p. 163.

39 Idem, ibdem.

40 Idem, p. 161.

41 Esteban LYTHGOE. “¿Una superación de los límites de la representación? La reelaboración del debate en Frank Ankersmit y su recurso al testimonio. In: Revista Latinoamericana de Filosofía, v.XXXVI, n.2, 2010, p. 175.

42 Marc NICHANIAN. "A morte da testemunha: por uma poética do 'resto' (reliquat0. In: Márcio SELIGMANN-SILVA, Jaime GINZBURG e, Francisco Foot HARDMAN (orgs.). Escritas da violência. Rio de Janeiro: 7Letras, 2012. (Volume I: o testemunho), p. 21.

43 Marc NICHANIAN. "A morte da testemunha: por uma poética do 'resto' (reliquat0. In: Márcio SELIGMANN-SILVA, Jaime GINZBURG e, Francisco Foot HARDMAN (orgs.). Escritas da violência. Rio de Janeiro: 7Letras, 2012. (Volume I: o testemunho), p. 19.

44 Enzo TRAVERSO. "La singularidad de Auschwitz. Um debate sobre el uso público de la historia”. In: Pasajes, n.17, 2005, p. 114.

45 LACAPRA, Dominick. Escribir la historia, escribir el trauma. Buenos Aires: Nueva Visión, 2005, p. 105.

46 Verónica TOZZI. "The epistemic and moral role of testimony”. In: History and Theory, 51, 2012, p. 2.

47 Verónica TOZZI. "Posguerra, realismo figural y nostalgia. La experiencia de Malvinas". In: Signos Filosóficos, v.X, n.19, 2008, p. 122.

48 Dominick LACAPRA. Escribir la historia, escribir el trauma. Buenos Aires: Nueva Visión, 2005, p. 110-11.

49 Cláudio Pereira ELMIR. "Desafios metodológicos da literatura de testemunho para o trabalho do historiador." In: Ana Lúcia Liberato TETTAMANZY, Jocelito ZALLA e Luís Fernando Telles D’AJELLO (orgs.). Sobre as poéticas do saber: pesquisas e reflexões em oralidade. São Paulo: Letra e Voz, 2010, p. 156.

50 Beatriz SARLO. Tempo passado. Cultura da memória e guinada subjetiva. São Paulo: Companhia das Letras; Belo Horizonte: Editora da UFMG, 2007, p. 47.

51 Idem, p. 52.

52 Idem, p. 57.

53 Idem, p. 70. 
54 Hayden WHITE. "Figural Realism in Witness Literature". In: Parallax, n.1, 2004, p. 114.

55 Verónica TOZZI. "The epistemic and moral role of testimony". In: History and Theory, 51, 2012, p. 6.

56 Idem, p. 12.

57 Judith BUTLER. "Primo Levi for the present. In: Frank ANKSERSMIT, Ewa DOMANSKA e Hans KELLNER (eds.). Re-figuring Hayden White. Stanford: Stanford University Press, p. 284.

58 Verónica TOZZI. Opus cit. p, 16.

59 Idem, p. 14.

60 Idem, p. 16.

61 Dominick LACAPRA. Escribir la historia, escribir el trauma. Buenos Aires: Nueva Visión, 2005, p. 107.

62 Márcio SELIGMANN-SILVA. "Narrar o trauma: a questão dos testemunhos de catástrofes históricas". In: Psicologia Clínica, v.20, n1, 2008, p. 69.

63 Dominick LACAPRA. Escribir la historia, escribir el trauma. Buenos Aires: Nueva Visión, 2005, p. 109.

64 Márcio SELIGMANN-SILVA. Opus. Cit. p. 70.

65 OFFENSTADT, Nicolas. "Le témoin et 1'historien". In: DÉLACROIX et al (dir). Historiographies: concepts et débats II. Paris: Galimard, 2010, p. 1242. 